ISSN 0103-5150

Fisioter. Mov., Curitiba, v. 29, n. 1, p. 103-12, Jan./Mar. 2016

Licenciado sob uma Licença Creative Commons

DOI: http://dx.doi.org.10.1590/0103-5150.029.001.A011

\title{
Prevalence of musculoskeletal pain and impact on physical function and health care services in Belterra/PA
}

\author{
Prevalência de dor musculoesquelética, impacto na funcionalidade \\ e implicações no serviço de saúde de Belterra/PA
}

\section{Paulo Henrique dos Santos Mota, Bruna Leite Gaudereto, Maria Regina Alves Cardoso, Ana Carolina Basso Schmitt*}

Universidade de São Paulo, (USP), São Paulo, SP, Brazil

\begin{abstract}
Introduction: Musculoskeletal pain worth being investigated for being a multidimensional prevalent phenomenon, difficult to be understood which may have as main factors: tissue injury as well as emotional, social and environmental aspects. It is essential to know the specificity of the pain to define strategies for disease prevention and health promotion of the population. Objective: To estimate the prevalence of musculoskeletal pain, describing its features and functional implications in population from Belterra/Pará. Method: In a descriptive study, there were evaluated subjects who participated in activities of the project Bandeira Científica. Prevalence of pain was estimated with a confidence interval of 95\%. Descriptive measures were used to characterize pain and consequences for functionality. Results: 453 subjects were interviewed, the mean age was 44.3 years old $(S D=18.0)$ and $69.6 \%$ were women. Prevalence of chronic pain was $62.5 \%$ and of back pain was $55.0 \%$. Almost daily pain was felt by $67.9 \%$ and by $69.6 \%$ the intensity was strong or unbearable during crisis. Individuals with unbearable intensity and daily frequency of symptoms reported
\end{abstract}

* PHSM: MSc, email: paulo.mota@usp.br BLG: grad, email: bruna.gaudereto@gmail.com MRAC: PhD, email: rcardoso@usp.br ACBS: PhD, email: carolinaschmitt@usp.br 
difficulty to perform heavy activities (91.5\%) and to remain in the same position (82.9\%). Conclusion: The prevalence of pain was high, of chronic feature, with high intensity and high frequency, long duration, most frequently in the vertebral column. The pain had interference in the performance of heavy activities and maintaining the same posture in people with greater intensity and frequency of pain.

Keywords: Pain. Epidemiology. Health services.

\section{Resumo}

Introdução: A dor musculoesquelética merece ser investigada por ser um fenômeno prevalente, multidimensional e de difícil compreensão, podendo ter como fatores principais: lesões teciduais, aspectos emocionais, socioculturais e ambientais. Assim, conhecer a especificidade da dor é essencial para definir estratégias de prevenção da doença e de promoção de saúde da população. Objetivos: estimar a prevalência de dor musculoesquelética e descrever as características da dor, o impacto na funcionalidade na população de Belterra/Pará e suas implicações no serviço de saúde municipal. Método: Em estudo descritivo foram avaliados indivíduos que participaram das atividades desenvolvidas pelo projeto Bandeira Científica. A prevalência de dor foi estimada com intervalo de confiança de 95\% e medidas descritivas foram usadas para caracterizar a dor e as consequências para funcionalidade. Resultados: Foram entrevistados 453 indivíduos, a idade média foi de 44,3 \pm 18,0 anos, 69,6\% eram mulheres. A prevalência de dor crônica foi de $62,5 \%$ e de dor na coluna 55,0\%. A dor era sentida quase diariamente por $67,9 \%$ dos indivíduos e em 69,6\% a intensidade era forte ou insuportável na crise. Indivíduos com intensidade insuportável e frequência diária do sintoma relataram maior dificuldade para atividades pesadas (91,5\%) e para manter-se na mesma posição (82,9\%). Conclusão: A prevalência de dor foi alta, de caráter crônico, com elevada intensidade e frequência, longa duração e maior frequência na coluna. A dor teve interferência na realização de atividades pesadas e manutenção da mesma postura em pessoas com maior intensidade e frequência de dor.

Palavras-chave: Dor. Epidemiologia. Serviços de saúde.

\section{Introduction}

Musculoskeletal pain is a prevalent multidimensional phenomenon which has difficulty understanding. Tissue injury as well as emotional, social and environmental aspects might be involved in this problem (1). Several diseases may result in chronic pain, defined as those occurring during a period greater than three months $(2,3,4)$. Chronic pain may be caused by intense mechanical injury, short and repeated overloads, joint immobilization, as well as inflammatory, degenerative and neoplastic diseases, birth defects, muscular weakness, rheumatic predisposition and others $(5,6)$. The prevalence of chronic pain in the population is around $20 \%$ (7). It may be considered a public health problem due to frequent absences from work, temporary or permanent disability and high healthcare costs (8). However, it has been reported that the cost-efficacy of pain care is highly favorable when complementary resources and therapies are used, with intervention and follow-up by a pain care multidisciplinary team (9). Therefore, it is essential to know the pain specificity to define strategies for disease prevention and health promotion.

The prevalence of musculoskeletal pain varies depending on the age and specificity of the population. In the SABE study, a cohort of elderly people in the city of São Paulo, chronic pain (especially musculoskeletal pain) was reported by $29.7 \%$ of the elderly (11). For nurses, the prevalence of musculoskeletal pain in the limbs was $65.6 \%$ (11) and for truck drivers the referred pain was $53.5 \%$ (12). Specifically, low back pain is the most common musculoskeletal disorder in industrialized societies, affecting $70 \%$ to $80 \%$ of adults at some point in life. It has predilection for young adults in economically active phase, being one of the most common reasons for total or partial disability retirement (13).

The pain may have important implications for people's lives, as it is related to factors such as depression, physical and functional disability, dependency, social withdrawal, changes in family dynamics and economic imbalance. It starts to direct and to limit the decisions and behaviors of the person, being that, many times, the inability to control it brings physical and mental 
suffering (14). Sardá Junior et al. (7) point out that there is no direct and linear relationship between lesion location, pain intensity and disability levels or suffering. Thus, it is necessary to increase the understanding of this process beyond the pain pathophysiology to fully understand this disability.

Functional capacity is related to autonomy and independence of the individual in performance of daily activities. Functional incapacity is understood as the presence of difficulty or impossibility in the performance of certain gestures and certain daily activities (15).

In Brazil, the care of chronic pain is described in the Clinical Protocol and Therapeutic Guidelines for Chronic Pain (16), which considers diagnosis, treatment criteria and control of service flows established in the health care system under responsibility of states and municipalities. Musculoskeletal pain is a type of pain referred in that protocol, though it is still necessary to know its demand to structure the offer of actions and services in the Brazilian Health System.

Nowadays, one of the strategies for population assistance for musculoskeletal pain could occur through a line of care in healthcare network. Given the chronic nature of the pain, networks need to be established through the integration of health care in a continuous and coordinated manner for a given population, considering time, cost, quality and adequate location $(17,18)$. Being so, it is necessary to understand the epidemiology of musculoskeletal pain and its implications in people's everyday lives.

Therefore, the purpose of this study was to estimate the prevalence of musculoskeletal pain, to describe the characteristics of the pain and its impact on functionality in the population of Belterra/ Pará, as well as the implications for the municipal health service.

\section{Materials and Methods}

This descriptive study was conducted in the context of actions of a university extension project from the Faculty of Medicine/University of São Paulo Bandeira Científica - in the city of Belterra, state of Pará, North Brazil, in December 2011. The city was selected due to its size in number of inhabitants (16.318 according to the Instituto Brasileiro e Geografia e Estatística (IBGE, 2010) (9), its low Human Development Index of 0.647 (PNUD, 2000), and the coverage by the Family Health greater than $70 \%$ of the population. Six municipal strategic locations were selected to conduct data collection, considering the number of inhabitants and facility of access for the residents: two points in the urban area, two in the highlands (rural area), and two on the banks of Tapajós River. Data collection was previous to any activity performed by the subjects within the Project.

Historically, a high prevalence of musculoskeletal complaints has been reported in the appointments made by the extension project Bandeira Científica, from the University of São Paulo. Therefore, the physiotherapy team conducted a screening on musculoskeletal pain in this expedition to Belterra/Pará, in 2011.

Two aspects were considered as eligibility criteria in this study: demand for participation in any activity of the project in joint action with the Secretariat of Health and individual's ability to answer, independently, the questionnaire. Data from the individuals who refused to participate in the study were not included in the analysis presented herein. Therefore, we investigated the reports of musculoskeletal pain and its consequences. All participants or their legal guardians, when minors, signed an informed consent.

Convenience sampling was used, i.e., study participants were those individuals who looked for the activities of the Project Bandeira Científica as they were interested in taking care of their own health.

Thus, 453 individuals were investigated, number enough to meet the proposed objectives, considering the lower prevalence of musculoskeletal symptoms in the population (36.5\%) (19) with a margin of error of 0.04 in $95 \%$ of the possible samples.

This study was authorized by the Department of Municipal Health of Belterra/PA and approved by the Ethics Committee of the Faculty of Medicine, University of São Paulo (Process no 461/11).

The authors recognize some limitations of this study. Considering its cross-sectional design, it is not possible to make causal inference between pain and functionality. To avoid errors, validated questionnaires, supplemented with important information to describe the pain such as duration and frequency, were used. However, a number of interviewers were involved in data collection, which could potentially lead to bias. To minimize this risk, the interviewers were thoroughly trained prior to fieldwork. Despite the convenience sampling being a limitation of the study, care was taken in selecting six strategic locations in the city. This allowed the sampling 
distribution regarding socio-demographic variables being close to that of the total population, as seen mainly in the distribution of age and household income. However, we cannot discard the possibility of having overestimated the prevalence.

\section{Dependent variable}

The presence of musculoskeletal pain was investigated through an adapted Nordic Questionnaire, containing the report of the respondent on the site of pain (body, upper limbs and lower limbs) (14) and with questions about the pain characteristics: intensity verified by using the visual analogue scale of pain in crisis and at the moment of the interview (20); the frequency - indicated by the number of days with pain in a month; and duration - how long they report having musculoskeletal pain. Complaints lasting for more than three months were considered as chronic pain $(2-4)$.

\section{Independent variables}

Besides investigating the reason for seeking the assistance of the Bandeira Científica, the individuals were asked about age, gender, place of residence, income, education, receiving Bolsa Família (government financial assistance), visit of community healthcare agent, physical activity and use of integrative and complementary practices. Questions related to labor activity as: current work, hours of work per day and sick leave due to referred pain were also made. Finally, it was used an adaptation of the Roland Morris Disability Questionnaire (8) to check the functional capacity, by using questions about daily activities such as: heavy, moderate and light activities; climbing stairs; kneel down; walk less and more than five minutes; take a shower; remain in the same position; sleep; carry out transfer and stay in the standing posture. The possible answers for these questions were: not difficult, little difficulty, much difficulty or lack of performance because of the pain.

\section{Data analysis}

Data were analyzed using Stata Program, version 11.0. The prevalence of musculoskeletal pain was estimated with the respective confidence interval of 95\% and descriptive measures of central tendency and dispersion were used for pain characteristics and consequence to the functionality.

\section{Results}

Table 1 describes the sociodemographic characteristics of people with and without pain who sought the "Bandeira Científica" program in the city of Belterra/PA and of the city's population informed by the Brazilian Institute for Geography and Statistics. 453 individuals aged 13-84 years old were interviewed, with mean age of $44.3 \pm 18.0$ years, being that $69.6 \%$ were women. Almost half the population had monthly family income of up to one minimum wage $(44.5 \%)$ and most did not complete elementary school (56.5\%).

The prevalence of musculoskeletal pain was $64.5 \%$ (95\% CI: 60.0\%-68.9\%). Out of 292 (64.5\%) people who complained of pain, $63.1 \%$ (95\% CI: $57.4 \%$ $68.6 \%$ ) reported having sought care in the "Bandeira Científica” program because of this problem.

Figure 1 shows the locations, the frequency, the duration and the intensity during the crisis and at the moment of musculoskeletal symptoms. When they were asked about the location of the pain, the spine (cervical, thoracic and lumbar) was the most cited (158 persons, $55.0 \%$ ), followed by lower limbs (62 persons, $21.6 \%$ ).

Regarding pain intensity at the time of the interview, the majority of respondents reported little (71 persons, $24.5 \%$ ) or moderate pain (102 people, $35.7 \%)$. However, the pain reached strong or unbearable intensity in the crisis in $202(69.6 \%)$ respondents. Many people, 226 (67.9\%), reported pain almost every day (from 21 to 30 days per month).

Chronic pain, characterized by being present for at least three months, had a prevalence of $62.5 \%$ (283 persons), being that 208 (45.9\%) reported the existence of the pain for more than six months.

Among people with pain, 142 (32.2\%) reported that they have already been or are away from their labor occupations because of the pain, being that 68 $(47.9 \%)$ remained away for at least a day. When they were asked about the cause of the onset of musculoskeletal complaints, 108 (38.4\%) respondents mentioned the work carried out and $8.9 \%$ poor posture. 
Table 1- Distribution of people with and without pain who sought the "Bandeira Científica" and of population of Belterra, according to sociodemographic characteristics and habits, Belterra, PA, 2011

\begin{tabular}{|c|c|c|c|c|c|}
\hline \multicolumn{2}{|c|}{ Characteristics \# } & Pain & Without Pain & Total & Municipal population* \\
\hline \multicolumn{2}{|l|}{ Entrevistados } & $292(64.5)$ & $161(35.5)$ & $m(10)$ & mos \\
\hline \multirow[t]{7}{*}{ Age } & 13-19 & $17(39.5)$ & 26 & $43(10.2)$ & $2452(21.4)^{\star * *}$ \\
\hline & $20-29$ & $21(38.2)$ & 34 & $55(12.9)$ & $2485(21.7)$ \\
\hline & $30-39$ & $52(61.9)$ & 32 & $84(19.8)$ & $2143(18.8)$ \\
\hline & $40-49$ & $52(69.3)$ & 23 & $75(17.6)$ & $1587(13.9)$ \\
\hline & $50-59$ & $62(81.6)$ & 14 & $76(17.9)$ & $1255(11.0)$ \\
\hline & $60-69$ & $32(76.2)$ & 10 & $42(9.9)$ & $804(7.0)$ \\
\hline & $70-84$ & $37(74.0)$ & 13 & $50(11.7)$ & $701(6.2)$ \\
\hline \multirow[t]{2}{*}{ Gender } & Male & $88(66.2)$ & 45 & $133(30.4)$ & $8481(52.0)$ \\
\hline & Female & $194(63.6)$ & 111 & 305 (69.6) & $7837(48.0)$ \\
\hline \multirow[t]{4}{*}{ Education Level } & $\begin{array}{c}\text { Incomplete } \\
\text { Elementary School }\end{array}$ & $178(69.0)$ & 80 & $258(62.5)$ & 8660 (79.2) \\
\hline & Elementary School & $36(50.0)$ & 36 & $72(17.4)$ & $1842(16.8)$ \\
\hline & High School & $37(60.7)$ & 24 & $61(14.8)$ & $186(1.7)$ \\
\hline & College & $14(63.6)$ & 8 & $22(5.3)$ & $241(2.2)$ \\
\hline \multirow{2}{*}{$\begin{array}{l}\text { Place of } \\
\text { residence }\end{array}$} & Urban & $111(68.5)$ & 51 & $162(35.8)$ & $6852(42.0)$ \\
\hline & Rural & $181(62.2)$ & 110 & $291(64.2)$ & $9466(58.0)$ \\
\hline \multirow[t]{2}{*}{ Physical Activity } & Yes & $90(60.4)$ & 59 & 149 & - \\
\hline & No & $186(65.9)$ & 96 & 282 & - \\
\hline \multirow[t]{4}{*}{ Profession } & Farm worker & $115(70.6)$ & 48 & 163 & - \\
\hline & Others & $65(57.0)$ & 49 & 114 & - \\
\hline & Housewife & $66(58.4)$ & 47 & 113 & - \\
\hline & Unemployd/ retired & $42(72.4)$ & 16 & 58 & - \\
\hline \multirow{5}{*}{$\begin{array}{l}\text { Monthly family } \\
\text { income (one } \\
\text { minimum wage) }\end{array}$} & $0 \leq 1 / 2$ & $65(63.1)$ & 38 & $103(25.8)$ & $1018(25.7)$ \\
\hline & $1 / 2-1$ & $62(62.6)$ & 37 & 99 (24.9) & 731 (18.4) \\
\hline & $1-2$ & $91(66.9)$ & 45 & $136(34.2)$ & 1154 (29.1) \\
\hline & $2-5$ & $22(59.5)$ & 15 & $37(9.3)$ & $815(20.6)$ \\
\hline & $>5$ & $15(65.2)$ & 8 & $23(5.8)$ & $244(6.1)$ \\
\hline \multirow{2}{*}{$\begin{array}{l}\text { "Bolsa Família" } \\
\text { government } \\
\text { financial } \\
\text { assistance }\end{array}$} & Yes & $120(57.1)$ & 90 & 210 & - \\
\hline & No & $156(70.6)$ & 65 & 221 & - \\
\hline \multirow{2}{*}{$\begin{array}{l}\text { Community } \\
\text { health worker }\end{array}$} & Yes & $238(63.8)$ & 135 & 373 & - \\
\hline & No & $38(65.5)$ & 20 & 58 & - \\
\hline \multirow{2}{*}{$\begin{array}{l}\text { Integrative and } \\
\text { complementary } \\
\text { practice }\end{array}$} & Yes & $188(69.9)$ & 81 & 269 & - \\
\hline & No & $88(54.3)$ & 74 & 162 & - \\
\hline
\end{tabular}

Note: \# number of respondents 453 . The total number of people for each variable was not the same due to lack of answers

* IBGE/2013

** Proportion of pain in persons with each variable

$* * *$ Estimated data 
With regard to the functional activities of individuals in pain, the majority did not present great difficulty in performing them, but $238(84.1 \%)$ had decreased functionality to heavy activities, $173(60.28 \%)$ to stay up and 199 (69.58\%) to crouch (Figure 2A). Individuals with unbearable pain intensity and daily frequency of the symptom (56 persons) reported great difficulty to perform heavy activities $(43 ; 91.5 \%)$ as walking (32; 66.7\%), kneeling (32; 66.7\%), stand up (38; 79.2\%), carry out transfer $(31 ; 63.4 \%)$, climb stairs $(28 ; 63.6 \%)$, and remain at the same position (39; 82.9\%) and less trouble in light activities (14; $29.2 \%)$ and bathing $(17 ; 36.2 \%)$ (Figure 2B).

\section{Discussion}

As this study, several others have found high prevalence of musculoskeletal pain, even with variations in the definition of pain, methods, study populations and instruments used. Brattberg et al. (21) investigated the residents of Sweden by mail and 66\% reported pain. In a similar study, Elliott et al. (22) found pain among $61 \%$ of the users of the health system in Scotland. In the population of Southern Brazil, such prevalence reached $61.4 \%$ (23). However, considering chronic pain as the presence of the pain for a period longer than three months, Verhaak et al. (2) found in a literature review prevalences ranging from $7 \%$ to $40 \%$, values lower than that found in our study of $62.5 \%$.

The body location most affected in the individuals interviewed in our study was the vertebral column, as also observed in other studies $(21,22)$. This can be justified because it is a region vulnerable to repeated patterns of movements and to mechanical overhead related to labor activities, mainly those that require great physical demand (24).

By analyzing the intensity of pain, $60.2 \%$ of the individuals interviewed in this study had little or moderate pain in the day of the interview, but in times of crisis, $69.6 \%$ reported strong or unbearable intensity. In a study from 2010, Sardá Junior et al. (8) observed that $47.3 \%$ of subjects had severe pain and $30.2 \%$ moderate.

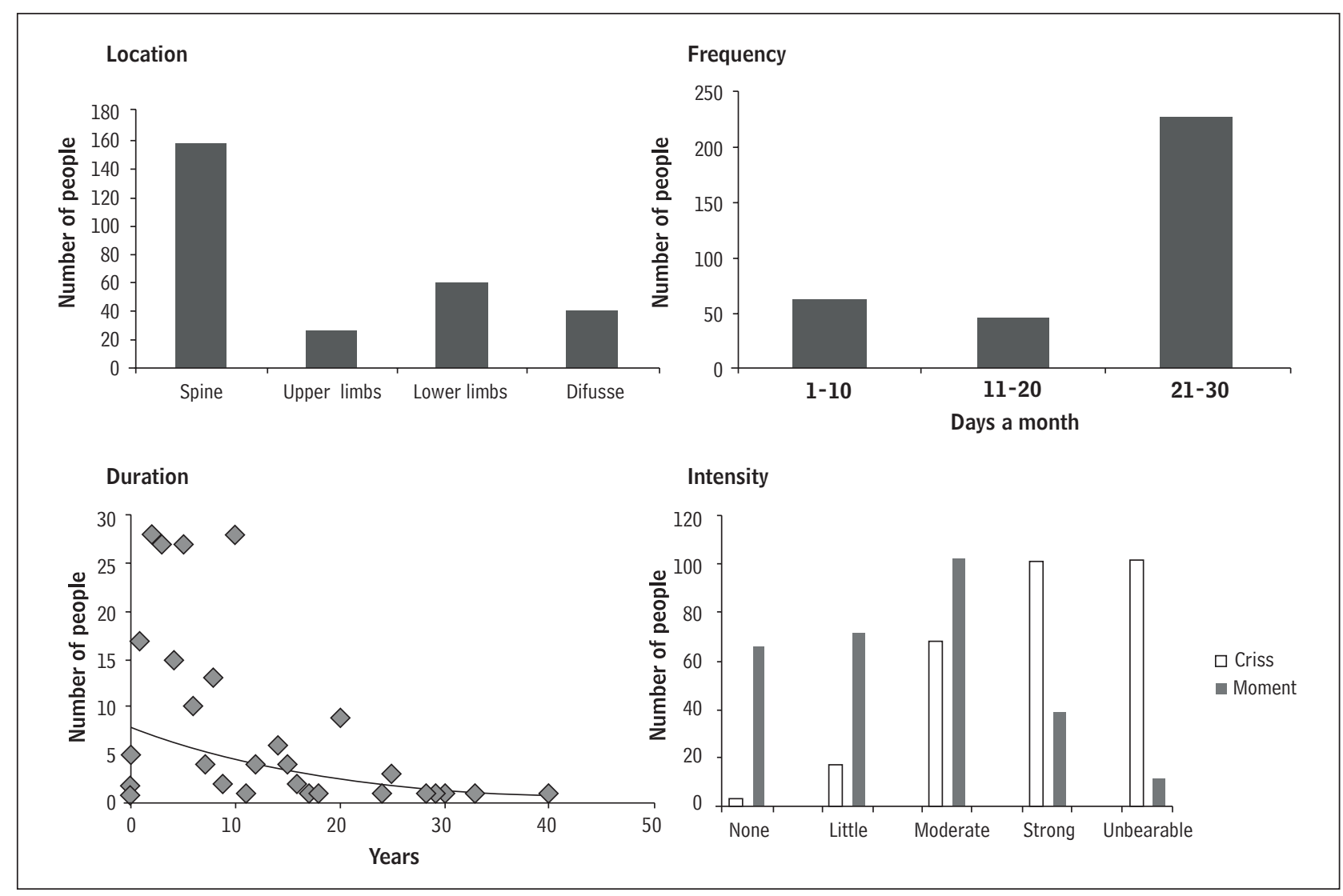

Figure 1 - Distribution of people with musculoskeletal pain, according to location, frequency, duration and intensity, Belterra, PA, 2011 


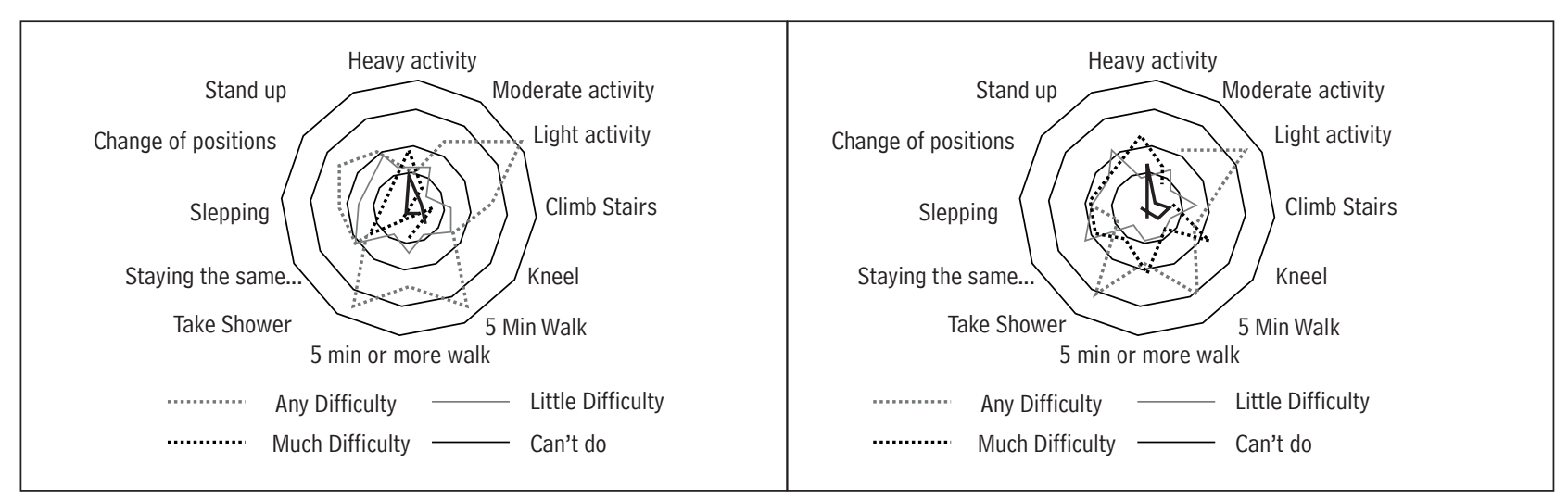

Figure 2 - Distribution of people with musculoskeletal pain, according to restrictions of daily activities. Belterra/PA, 2011. (A) All people with pain; (B) Individuals who reported daily pain and unbearable intensity during time of crisis

The osteoarticular pain and the functionality are elements connected to the health of the individuals and, thus, they influence the mode of interaction between themselves and between them and the environment (25).

For James (26), it is of great importance to establish the relationship between the presence of pain for a considerable period of time and the limitation to the functionality, mainly in activities that require great energy expended as: walking, kneeling, standing, perform transfer and heavy activities. Such functional implications appear more frequently in individuals who report daily pain and moderate and unbearable intensities. We found that $32.2 \%$ of the study persons justified sick leave by pain, besides, most have presented difficulties in various activities of everyday life.

We can highlight the musculoskeletal pain and its association with musculoskeletal disorders related to work as generators of varying degrees of functional disability, being considered one of the most serious problems in the field of occupational health. Musculoskeletal diseases have become the leading cause of illness at work, within the ten most prevalent diagnoses nine are musculoskeletal diseases. These disorders are responsible for most of the work absenteeism and of the severance costs, both in the Brazilian population and in the world population (25).

Individuals with chronic pain become a significant burden for health services, social security institutions and insurance companies. According to a population survey conducted in Brazil, more than 1/3 of our population believes that chronic pain commits the usual activities and over $3 / 4$ considers that the chronic pain limits the recreational activities, social and family relationships. Due to pain, approximately $50 \%$ to $60 \%$ of patients become partially or completely disabled, transiently or permanently (27).

Having been held in a distant region of the main Brazilian cities and with inclusion of residents of different localities of the city with difficult access, this study brings a vision of a little-known population. This achievement was only possible through the encounter between external health practices at the municipal reality and the individual active search for assistance. Thus, a limiting and disabling aspect as musculoskeletal pain made it possible the rise of important aspects of the health status and care of this population.

The importance of the findings of this study further increases when verified that for many people the pain occurred for several years, being that $63.1 \%$ sought the "Bandeira Científica" program presenting that pain as the primary complaint. Thus, one can ask whether these individuals: (1) seek help, but the problem is not solved, generating a new search for professional or (2) have difficult access to health facilities in the region or (3) believe that professionals from a large urban center such as São Paulo have better technical and scientific resources to care for their complaints.

The piece of information that may contribute to the answer this question is that $86.5 \%$ of the respondents reported that they receive visits from community health agents, thus showing that there is some access to health care. However, there is no information whether this access is complete in the care networks, since adequate services and professionals might not assist these individuals. This fact can also be observed in Canadian and Australian studies, which show that in the countryside access to health services are unevenly distributed 
compared to urban areas due to poor distribution of health professionals and equipment throughout the territory $(28,29)$. This difficulty regarding the complete access to health care might be motivated by structural barriers and lack of information about services (29).

We believed that a follow-up of patients with musculoskeletal pain already exists, however the municipal health system cannot resolve this type of complaint for not having an organized network care and sufficient professionals for this demand, maybe because they are not used to this type of question. Associated to this is the fact described by Sibley and Weiner (29) that residents of inland areas report lower health care needs when compared with individuals from central areas, and postpone the search for health services when they are not in economic and social favorable moments.

The results show high prevalence of pain among the study population. This great demand for public health in Belterra/PA is important to generate reflections on the profile of people with pain, its associated factors and the consequences for the population in order to rethink the planning of an articulating line to pain care network and its human resources. Mata et al. (25) also warned that health services direct their actions towards these problems, identifying them, in everyday life, by listening to individuals and families covered by the Brazilian primary care, and then trying to solve them creatively, especially focusing on promotion and prevention actions to avoid further illness in these individuals.

Finally, the pain characteristics and the implication on the functionality observed in this study may be similar in many cities in Brazil, as the majority of these cities, 4,037 out of 5,575 municipalities, has up to 20,000 inhabitants and is located in the countryside (30). The knowledge of the facts mentioned here is important for the physical therapist and manager as it permits understanding and qualifying the demand, enabling the creation of actions and better organization of human resources looking at comprehensive health care by actions in collective health.

\section{Conclusion}

The prevalence of musculoskeletal pain was high and of chronic nature with high intensity in the crisis, being frequent and long-lasting. The most predominant site was the vertebral column. For the study persons, pain interfered with achieving heavy activities and maintaining the bipedal position. For those who reported unbearable pain and daily frequency, there was great difficulty in daily activities such as walking, kneeling, standing, performing transfer, climbing stairs and remaining in the same position. We emphasize the importance of these results for planning a physical therapy care line in the health care network for musculoskeletal pain in Belterra/PA, and in other similar municipalities, and we recommend new studies in other cities and analysis of causality relationship between pain and functionality.

\section{References}

1. Almeida ICGB, Sá KN, Silva M, Baptista A, Matos MA, et al. Chronic low back pain prevalence in the population of the city of Salvador. Rev Bras Ortop. 2008;43:96-102.

2. Frølund F, Frølund C. Pain in general practice. Pain as a cause of patient-doctor contact. Scand J Prim Health Care. 1986;4:97-100.

3. Croft P, Rigby AS, Boswell R, Schollum J, Silman A. The prevalence of chronic widespread pain in the general population. J Rheumatol. 1993;20:710-3.

4. Verhaak PF, Kerssens JJ, Dekker J, Sorbi MJ, Bensing JM. Prevalence of chronic benign pain disorder among adults: a review of the literature. Pain 1998;77:231-9.

5. Camanho GL, Imamura M, Arendt-Nielsen L. Gênese da dor na artrose. Rev Bras Ortop. 2011;46:14-7.

6. Zavarize SF, Wechsler SM, Lima AB, Martelli A. Dor Lombar Crônica: Implicações do Perfil Criativo como estratégia de enfrentamento. JMPHC J Manag Prim Heal Care 2014;5:188-94.

7. Fonseca JC, Lopes MJ, Ramos AF. Pessoas com dor e necessidades de intervenção: revisão sistemática da literatura. Rev Bras Enferm. 2013;66:771-8.

8. Sardá Júnior JJ, Nicholas MK, Pimenta CA de M, Asghari A, Thieme AL. Validation of the Roland Morris disability questionnaire for general pain. Rev Dor. 2010;11.

9. Dellaroza MSG, Pimenta CA de M, Matsuo T. Prevalence and characterization of chronic pain among the elderly living in the community. Cad Saúde Pública. 2007;23:1151-60. 
10. Dellaroza MSG, Pimenta CA de M, Duarte YA, Lebrão ML. Dor crônica em idosos residentes em São Paulo, Brasil: prevalência, características e associação com capacidade funcional e mobilidade (Estudo SABE). Cad Saude Publica. 2013;29:325-34.

11. Ribeiro NF, Fernandes R de CPF. Distúrbios musculoesqueléticos em membros inferiores em trabalhadores de enfermagem. Rev Baiana Saúde Pública. $2014 ; 35$.

12. Lemos LC, Marqueze EC, Moreno CR de C. Prevalência de dores musculoesqueléticas em motoristas de caminhão e fatores associados. Rev Bras Saúde Ocup. 2014;39:26-34.

13. Andrade SC de, Araújo AGR de, Vilar MJP. Back School: historical revision and its application in chronic low back pain. Rev Bras Reum. 2005;45:224-8.

14. Pinheiro FA, Tróccoli BT, Carvalho CV De. Validação do Questionário Nórdico de Sintomas Ósteomusculares como medida de morbidade. Rev Saúde Pública. 2002;36:307-12.

15. Grimley Evans J. Prevention of age-associated loss of autonomy: epidemiological approaches. J Chronic Dis. 1984;37:353-63.

16. BRASIL. Portaria No 1.0083. Brasilia: Ministério da Saúde; 2012.

17. Mendes EV. As redes de atenção à saúde. Cien Saúde Colet. 2010;15:2297-305.

18. PAHO. Integrated Health Service Delivery Networks: Concepts, Policy Options and a Road Map for Implementation in the Americas. Washington: 2011.

19. Silva VRL da, Menezes AMB, Noal RB. Sintomas articulares crônicos em adultos de Pelotas, Rio Grande do Sul, Brasil: prevalência e determinantes. Cad Saúde Pública. 2009;25:2571-81.

20. De Leon SP, Lara-Muñoz C, Feinstein AR, Wells CK. A comparison of three rating scales for measuring subjective phenomena in clinical research: II. Use of experimentally controlled visual stimuli. Arch Med Res 2004;35:157-62.

21. Brattberg G, Wikman A. TM. The prevalence of pain in a general population. The results of a postal survey in a county of Sweden 1989;37:215-22.
22. Elliott AM, Department of General Practice Aberdeen and Department of Public Health U of AMS, Smith BH, Penny KI, Medical Statistics Unit Edinburgh, UK U of EMS, Smith WC, et al. The epidemiology of chronic pain in the community. Lancet 1999;354:1248-52.

23. Kreling MCGD, USP, Londrina UE de, Cruz D de ALÉM da, Pimenta CA de M. Prevalence of chronic pain in adult workers. Rev Bras Enferm. 2006;59:509-13.

24. Matos MG, Hennington ÉA, Hoefel AL, Dias-da-Costa JS. Dor lombar em usuários de um plano de saúde: prevalência e fatores associados. Cad Saude Publica. 2008;24:2115-22.

25. Mata M de S, Costa FA da, Souza TO de, Mata ÁN de $\mathrm{S}$, Pontes JF. Pain and functionality in primary health care. Ciênc Saúde Coletiva. 2011;16:221-30.

26. James FR, Large RG, Bushnell JA, Wells JE. Epidemiology of pain in New Zealand. Pain 1991;44:279-83.

27. Teixeira MJ, Teixeira WGJ, Santos FP de S, Andrade DCA de, Bezerra SL, Figueiró JB, et al. Epidemiologia clínica da dor músculo-esquelética. Rev Med 2001;1.

28. Briggs AM, Slater H, Bunzli S, Jordan JE, Davies SJ, Smith AJ, et al. Consumers' experiences of back pain in rural Western Australia: access to information and services, and self-management behaviours. BMC Health Serv Res. 2012;12:357.

29. Sibley LM, Weiner JP. An evaluation of access to health care services along the rural-urban continuum in Canada. BMC Health Serv Res. 2011;11:20.

30. IBGE. IBGE Cidades;2013. [Cited in Aug. 2013]. Available from: http://www.ibge.gov.br/home/presidencia/noticias/noticia_visualiza.p hp?id_noticia=345.

Recebido: 09/08/2013

Received: 08/09/2013

Aprovado: 06/07/2015

Approved: 07/06/2015 
